\title{
Multilingual Students in Greek Schools: Teachers' Views and Teaching Practices
}

\author{
Lydia Mitits ${ }^{1}$ \\ 'Democritus University of Thrace, Greece \\ Email:1ydiamitits@gmail.com Tel:+306937131484
}

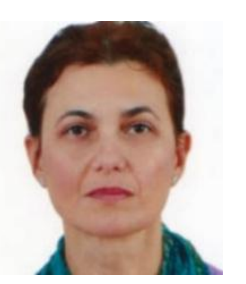

\begin{abstract}
The purpose of the study was to investigate the views held by teachers in Thrace, Greece with respect to their multilingual students and the teaching practices. A questionnaire (De Angelis, 2011) was used to assess teachers' beliefs about the role of prior linguistic knowledge, the teacher, the school and the family in the education of multilingual learners, as well as about their teaching practices. The effect of variables (gender, age, subject taught, teaching experience, intercultural education, and contact with languages) on teachers' attitudes and beliefs were examined. 60 primary and secondary school teachers, who mainly taught languages but also other school subjects, participated. They worked in an area comprising a significant number of multilingual learners with a non-Greek L1 belonging to the minority or immigrant families. Overall results suggest that teachers tend to share similar views and that the tested variables significantly affected their responses on a number of questions.
\end{abstract}

Keywords: Teachers' beliefs, Multilingualism, Teaching practices.

Citation | Lydia Mitits (2017). Multilingual Students in Greek Schools: Teachers' Views and Teaching Practices. Journal of Education and e-Learning Research, 5(1): 28-36.

History:

Received: 22 December 2017

Revised: 18 January 2018

Accepted: 22 January 2018

Published: 26 January 2017

Licensed: This work is licensed under a Creative Commons Attribution 3.0 License $($ (c) $)$ EY

Publisher: Asian Online Journal Publishing Group
Contribution/Acknowledgement: This study is one of a very few studies which have investigated teachers' beliefs and views of multilingualism and its role in the classroom. Its findings point out that those beliefs are generally shared both by Greek teachers but also across countries and cultures and that they are influced by various factors.

Funding: This study received no specific financial support

Competing Interests: The author declares that there are no conflicts of interests regarding the publication of this paper.

Transparency: The authors confirm that the manuscript is an honest, accurate, and transparent account of the study was reported; that no vital features of the study have been omitted; and that any discrepancies from the features of the study have been omitted
study as planned have been explained.

Ethical: This study follows all ethical practices during writing.

\section{Contents}

1. Introduction.

29

2. Previous Research

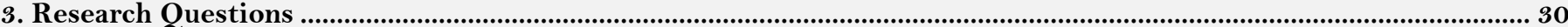

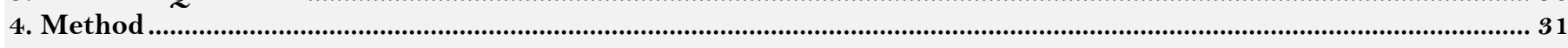

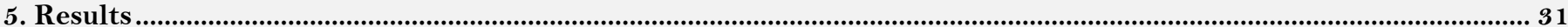

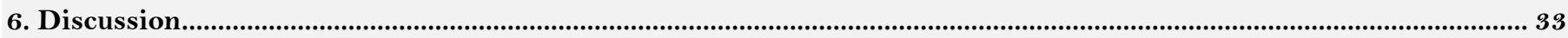

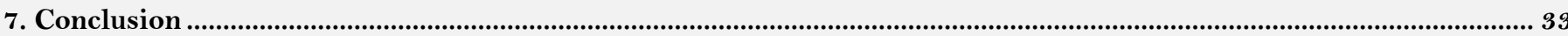

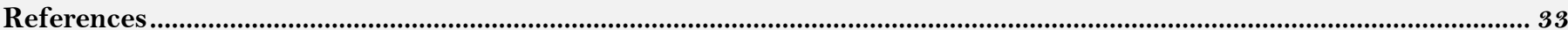




\section{Introduction}

The purpose of the study was to investigate the beliefs and opinions of primary and secondary school teachers in Thrace, Greece with respect to their multilingual students with the aim to determine how teachers view the role that prior linguistic knowledge plays in their students' education and in society in general, to record the role of the teacher, school and family in education of multilingual learners, to identify teachers' beliefs and attitudes towards their learners with a non-Greek L1, to investigate the teaching practices in order to suggest ways to improve them in the light of the findings. Variables that influence attitudes and beliefs were also examined. Those included: age, gender, teaching experience, subject matter taught, teaching context, prior linguistic knowledge, etc.

\section{Previous Research}

\subsection{A Multilingual Learner}

In the recent years the term multilingualism has increasingly been used instead of bilingualism, although different views can still be found in the literature (Cenoz, 2013). For the purposes of the present study multilingualism will be employed as the generic term to refer to two or more languages (Aronin and Singleton, 2008). Being multilingual has consequences on language, cognition and social background of a learner and this crosslinguistic interaction has been viewed in the literature either as a drawback or a benefit (Herdina and Jessner, 2002). Historically, research into multilingualism has shifted from early studies presenting multilinguals as greatly disadvantaged compared to monolinguals, to an overoptimistic view, as a result of the findings depicting multilinguals' cognitive advantages, to research results according to which multilinguals can have significant linguistic, cognitive and sociolinguistic advantages over monolinguals under certain conditions.

Although the early research recognized the importance of learning two languages, it mostly attributed limited linguistic and cognitive knowledge of a bilingual child to crosslinguistic influence (Jespersen, 1922). Later studies (e.g. (Hamers and Blanc, 1989; Cook, 1993)) also reported that second language learners underperform compared to native speakers in all cognitive areas. Also, multilingual underachievement in schools has frequently been reported. Lambert (1977) distinction between additive and subtractive bilingualism has contributed to the explanation of linguistic deficit and underachievement in certain groups of bilinguals, thus bringing the sociolinguistic aspect into the research into multilingualism. Jessner (1995) notes that the distinction between additive and subtractive bilingualism is crucial in explaining mutually connected individual and societal multilingualism. Additive bilingualism/multilingualism is the term used to refer to the positive results of being multilingual as it includes the acquisition of two or more socially prestigious languages while subtractive bilingualism/multilingualism includes negative affective and cognitive effects. It occurs in a situation where, for example, the first language of a multilingual is not the dominant language in the wider community or a prestigious one (e.g. in members of minority groups where both languages may be underdeveloped).

As for the benefits of multilinguals a widely reported one is that those learners appear to have developed new skills, such as metacognitive strategies, as a result of their prior language learning experience as well as a high level of metalinguistic awareness. Multilingual superiority in various cognitive skills as well as positive crosslinguistic relationships for conversationally-oriented and literacy-related language abilities have been reported in numerous studies (e.g. (Cummins, 1991; Kecskes and Papp, 2000)). Hakuta (1990) reported that even primary school multilingual students exhibited the ability to translate, which can serve as an effective method of developing their metalinguistic skills as well as literacy skills and proposed creating conditions for additive bilingualism and the holistic development of the native language early on in the child's education in order to achieve that goal. Malakoff (1992) also found that translation skills in multilinguals are related to their metalinguistic behavior, while other studies have shown multilinguals' advantages on measures of metalinguistic awareness, cognitive flexibility and creativity (e.g. (Bialystok, 1991; Titone, 1994; Baker, 1996)). Cognitive flexibility is another feature of multilingual learners recorded in a number of investigations according to which they are more divergent, creative, original and flexible learners who are more fluent and elaborate than their monolingual equivalents (Ricciardelli, 1992). Finally, besides language and cognition, multilinguals appear to outperform monolinguals in social skills by exhibiting higher pragmatic competence or communicative sensitivity (Genesee et al., 1975; Safont, 2005).

A multilingual learner in our study will be the term used for school age speakers/users of a home language or languages (L1) alongside the dominant language of a wider community (which is also the official language of schooling) (L2), and at least one foreign language as a part of their formal education program (FL).

\subsection{Multilingualism in Schools and in Greek Education System}

Baker and Prys (1998) describe ten different types of bilingual education. It is believed by the present researcher that their division can be expanded in principle to accommodate education with three or more languages and can be used to present the Greek education system, which can be described as a 'weak' form of multilingual education that leads to monolingualism or limited multilingualism by assimilating language minority children within the language majority society. At the same time, though, the public-school curricula also provide opportunities for incorporating elements of cultural pluralism and multiculturalism into teaching materials and practices, as well as for learning prestigious foreign languages (English, French, German, etc.). Also, within public schools, special reception Greek language classes are organized for learners with L1 other than Greek, who either come from repatriated, immigrant or refugee families. Besides public education, there are minority primary and secondary schools in Thrace for students with L1 Turkish, Pomak or Romani, in which dual language education system is applied. Half of the school subjects are taught in Greek and the other half in Turkish while English is taught as a foreign language.

There is some research into multilingualism in Greece which addresses learners' multilingualism mainly as an educational problem that leads to linguistic deficit and general underachievement, particularly with respect to proficiency in Greek (Damanakis, 1997; Nikolaou, 2000; Skourtou, 2002; Tressou and Mitakidou, 2003; Georgoyannis, 2006; Govaris et al., 2010). A limited number of studies, however, have focused on the importance of language maintenance of the linguistic minority students for the benefit of their cognitive and linguistic 
development. According to Tsokalidou (2005) teachers in Greece have not been trained and lack experience in intercultural educational approaches. Generally, not being aware of the potential benefits of multilingualism, they need to learn how to take advantage of the diverse linguistic and cultural background of their students. Teacher training concerning multilingualism should include the clarification of what multilingualism and linguistic diversity entail and how it can mediate and facilitate language learning (Skourtou, 2008; Gkaintartzi and Tsokalidou, 2011).

Another important feature of Greek schooling is that, as a result of linguistic assimilation tendency, there are difficulties in the smooth and balanced integration of linguistic minority learners (Gogonas, 2010) leading to signs of low self-esteem, school failure and other school-related problems (Nikolaou, 2000). Problems with individual multilingualism stem from social circumstances, one of which is the relationship between school and a linguistic minority student. The best indicators of school success seem to be the students' socioeconomic status and command of the school language. There are a number of factors which influence the chances of minority learners' school success. Those are (among others): the general atmosphere at the school, the curriculum and its meaningfulness to minorities, teacher education and the involvement of minority students' mother tongue (Reich et al., 2002). In one of the latest documents the Council of Europe (2010) outlines the aims of plurilingual and intercultural education, which is recommended to its member states in the light of the increasingly plural character of the European Union societies. One of the aims is the integration between foreign, majority, regional/minority and possibly migration languages taught in the school and other subjects in the curriculum. If such a curriculum is implemented it should, among others, enable learners to:

- $\quad$ expand and maintain their language repertoires;

- instruct themselves in their primary language (language of the home);

- learn a regional, minority or migration language, if this is what they and/or their parents desire;

- acquire the language competences needed for life in the community (particularly written production and reception competences) (CoE, 2010).

A paradox found in the attitudes of the Greek state and individuals is that they seem to value greatly and invest into the learning of prestigious foreign languages such as English, German and French, while, at the same time, ignore or neglect the fact that Greece is a multilingual country with many people who bring into it different languages and cultures (Damanakis, 1997; Gogonas, 2010).

\subsection{Teachers' Beliefs about Multilingual Learners}

De Angelis (2011) aptly points out that teachers have a great influence both inside and outside the classroom as their personal views and beliefs may lead to the use and/or maintenance of the home language of their students or not. For this reason, it is argued that insight into teachers' beliefs is necessary in order to understand and improve language teaching and students' learning (Borg, 2006). There appear to be a limited number of studies that have explored language teachers' beliefs about multilingualism and multilingual pedagogy.

Lasagabaster and Huguet (2007) investigated language attitudes of pre-service teachers towards languages in 9 European bilingual regions. A few years later, De Angelis (2011) reported on 176 secondary school teachers' beliefs about the role of prior language knowledge and the promotion of multilingualism in enhancing immigrant children's language learning. She administered a questionnaire to teachers from Austria, Great Britain and Italy, and found that, although the teachers tend to encourage learners to use their home languages, they believe that using home languages in class can delay and even impair the learning of the majority language. Another interesting finding is that many teachers never refer to learners' home language and culture in class. In the Greek educational context, Griva and Chostelidou (2012) studied teachers' beliefs and attitudes towards the development of multilingual competence and found that the participants recognized the importance of multilingual communicative competence in major European languages but were skeptical about the development of multilingualism.

In Germany, Heyder and Schadlich (2014) examined 297 FL teachers and their beliefs about multilingualism and reported that the majority were positive about the benefits of comparing languages in the classroom and the activities that had the potential to promote multilingualism., although they rarely used them in actual teaching. With respect to Polish pre-service and in-service English teachers' multilingual awareness and practices Otwinowska (2014) combined quantitative and qualitative methods and the main results from her studies indicate that experienced in-service teachers have greater multilingual awareness than pre-service teachers do. Also, multilingual teachers and more experienced ones showed greater awareness. In the same year, Gutierrez (2014) developed an instrument to assess the beliefs of teachers of Spanish, French and German as an L3 and the issues of third language acquisition. Another study which investigated a multilingual pedagogical approach in an L3 classroom was conducted in Norway by Haukas (2016). She reported that the teachers view multilingualism as a potentially positive asset, which has helped their own language learning. However, they do not assume the same for their students. In theory, though, the teachers support the view that collaboration across languages could enhance students' language learning.

What the review of the relevant literature tells us is that, although the studies discussed above were conducted in various countries with different learning contexts, they share similar results. Teachers who come from different countries seem to share positive beliefs about multilingualism and support its promotion. However, in practice they rarely do so in their own classrooms.

\section{Research Questions}

RQ1: Which are the most and least shared views about multilingualism by teachers in Greek primary/secondary education? RQ2: What is the effect of teachers' profiles (gender, age, subject taught, school type, intercultural education, and teaching experience) on their views about multilingualism?

RQ3: How does teachers' contact with other languages affect their views about multilingualism? 
(4) The distribution of responses on statements no.4 $(p=.012)$, no.13 $(p=.42)$ and no.21 $(p=.015)$ was not the same with respect to whether or not the teachers had received intercultural training or not. Those teachers who have never received training in intercultural education report that for students with $\mathrm{L} 1$ other than Greek it is more important to know a major international language than their home language and that they do not refer to the home language or culture of their students with L1 other than Greek in their teaching. On the other hand, those teachers who have participated in such in-service training express a strong belief that maintaining a home language helps students with L1 other than Greek maintain their home culture as well.

(5) With respect to the school type where the participants work, the independent-samples Kruskal-Wallis test rejected the null hypotheses on the following statements: no.1 $(p=.017)$, no.2 $(p=.029)$, no.3 ( $p=.013)$, no.7 $(p=.001)$, no. 8 ( $p=.006)$, no.14 $(p=.012)$, no.15 ( $p=.004)$, and no.17 ( $p=.004)$. Teachers who work in primary minority schools feel most strongly about it being their responsibility to help students with L1 other than Greek maintain their home language (no.1), followed by those teaching in primary public schools. Teachers from secondary minority education have mixed views, while those teaching in secondary public schools feel against this statement. The strongest agreement with the statement no.2 (Knowing a language helps students with L1 other than Greek learn another language) was reported by the teachers working in primary minority education, followed by secondary minority and primary public education, while those teaching in secondary public education do not share such a strong positive belief. A similar pattern is observed in the case of the statement no.3 (I would like to be more informed about the home language and culture of the students with L1 other than Greek). Whether students with L1 other than Greek are not interested in (no.7) or are ashamed of (no.8) speaking their home language in front of their school peers produced different responses, with teachers working in primary minority schools who strongly disagree with these views, followed by their colleagues from secondary public schools. Those who agree with these statements are teachers from primary public schools. The majority of teachers (primary minority, secondary public, and secondary minority schools) agree with the statement no.14 (The frequent use of the home language delays the learning of Greek). Next, only those teaching in primary minority schools agree that the school offers activities aimed at raising awareness about home language and culture of students with L1 other than Greek (no.15). Lastly, only teachers from minority schools (primary and secondary) agree that the teaching of the home language is the responsibility of the school (no.17).

(6) The effect of teaching experience on the responses was significant on statements no.2 $(p=.033)$, no.5 $(p=.036)$, no.6 $(p=.047)$ and no.11 $(p=.025)$ (Independent-samples Kruskal-Wallis test). In other words, while all the teachers agree/strongly agree with the view that knowing a language helps students with L 1 other than Greek learn another language (no.2), the least experienced teachers have the strongest positive view. Next, the most experienced teachers hold the strongest belief that students who are familiar with several languages will have more opportunities to succeed in their professional life (no.5). Also, the majority disagree with the view that for students with L1 other than Greek it is more important to know a major international language than their home language (no.6), with teachers with teaching experience between 6 and 10 years disagreeing the most. The least and the most experienced teachers differentiate themselves as for the statement no.11 (Parents of the students with L1 other than Greek do not seem to want their children to maintain their home languages) as they did not strongly disagree with this view.

\subsection{The Effect of Teachers' Contact with Other Languages on their Views about Multilingualism}

The participants were asked to respond to 5 yes/no questions (Q1-5) investigating their contact with other languages (see Table 2).

Table-2. Teachers' responses to questions about their contact with other languages

\begin{tabular}{|c|c|c|c|c|c|c|}
\hline \multirow[t]{2}{*}{ Questions about contact with languages } & \multicolumn{2}{|c|}{ yes } & \multicolumn{2}{|l|}{ no } & \multirow[t]{2}{*}{ missing } & \multirow[t]{2}{*}{ total } \\
\hline & n. & $\%$ & n. & $\%$ & & \\
\hline $\begin{array}{l}\text { Q1 Can you hold a basic conversation in a language that is not your } \\
\text { mother tongue? }\end{array}$ & 51 & 85.0 & 9 & 15.5 & $O$ & 60 \\
\hline $\begin{array}{l}\text { Q2 Do you have a frequent contact with native speakers of other } \\
\text { languages outside the school? }\end{array}$ & 45 & 75.0 & 12 & 20.0 & 3 & 60 \\
\hline Q3 Do you often use a language that is not your mother tongue? & 21 & 35.0 & 39 & 65.5 & $O$ & 60 \\
\hline Q4 Would you like to learn another foreign language? & 50 & 83.3 & 8 & 13.3 & 2 & 60 \\
\hline $\begin{array}{l}\text { Q5 Would you be interested in learning one of your students' home } \\
\text { languages? }\end{array}$ & 43 & 71.7 & 16 & 26.7 & 1 & 60 \\
\hline
\end{tabular}

Source: The background questionnaire adapted from De Angelis (2011)

The effect of their responses on the frequency of their answers to the 25 statements in the questionnaire was measured and found statistically significant for the following statements.

Q1. The responses to whether or not the participants could hold a basic conversation in another language were significant on statements: no.4 $(p=.021)$, no.6 ( $p=.015)$, no.7 ( $p=.013)$, no.8 ( $p=.019)$, no.13 ( $p=.039)$ (Independentsamples Mann-Whitney U test). Those teachers who reported not having any experience with other languages agree that they do not refer to their students' home languages in their teaching; they believe that their students would benefit more from knowing an international language than their home language; they are of the view that their multilingual students are not interested in or are ashamed of speaking their home language in front of their peers; and they also agree with the statement that students with L1 other than Greek can maintain their culture without maintaining their home language.

Q2. With respect to teachers' contact with native speakers of other languages, significant differences were found on statements no.4 ( $p=.014)$, with teachers who do not have a frequent contact saying they do not refer to their students' home languages, and no.5 $(p=.028)$, with the same group disagreeing that students who are familiar with several languages will have more opportunities to succeed in their professional life.

Q3. When the teachers were asked if they would be interested in learning one of their students' home languages the Independent-samples Mann-Whitney U test showed significant differences on 5 statements: no. 1 
$(p=.010)$, no.3 $(p=.001)$, no. 4 ( $p=.001)$, no.6 $(p=.013)$, no.18 ( $p=.017)$. Those teachers who responded negatively to the above question also agree with the statement that they do not usually make references to their students' home languages in their teaching and they believe that for those learners it is more important to know a major international language than their home language. On the other hand, they disagree with the statement that it is the teacher's responsibility to help students with L1 other than Greek maintain their home language; they would not like to be informed about their students' home languages; and they also disprove that maintaining the home language helps students with L1 other than Greek maintain their home culture as well.

Q4. When asked if they would like to learn another foreign language those teachers who answered positively also agree that parents of the students with L1 other than Greek must do more to help their children maintain their home language (statement no.10, $p=.029$ ).

Q5. The nonparametric independent-samples Mann-Whitney U test which examined the effect of the variable How often do you use a language that is not you mother tongue? - revealed no statistically significant differences and the null hypotheses were retained.

\section{Discussion}

It appears, from the above presented findings and the review of the limited number of relevant studies, that teachers' beliefs and views of multilingualism and its role in the classroom are characterized by some similarities within and across countries and cultures. The teachers in the present study recognize the importance of speaking foreign languages, mostly as a means of ensuring professional success, which is in line with this very strongly held view in the Greek society. Greek families invest a lot of time, effort and money into providing their children with the opportunities to obtain numerous foreign language certificates, which are of primary importance in any field of professional or academic life in Greece. At the same time, they also believe that home languages and home cultures are inseparable, yet the multicultural practices applied in Greek schools rarely contain reference to the home language of the multilingual learners and restrain themselves to the folklore elements of multicultural/intercultural education. This is probably linked to the commonly shared view by the participants that it is the responsibility of the family to teach the home language to their children rather than of the official schooling, which can be justified as the curricula do not contain such aims and objectives. However, the present teachers strongly believe in the positive influence of learning additional languages and recognize their benefits for further language learning, which is consistent with numerous findings (Hakuta, 1990; Cummins, 1991; Malakoff, 1992; Kecskes and Papp, 2000).

Although the general views are shared within the particular group of teachers and the Greek education system (Griva and Chostelidou, 2012) as well as with their colleagues in other educational contexts (De Angelis, 2011; Heyder and Schadlich, 2014; Otwinowska, 2014; Haukas, 2016). By examining the teachers' profiles, a clearer conclusion of how other variables influence those generally held views and beliefs is drawn. One significant finding is related to the subjects that the teachers taught, with language teachers recognizing the importance of having at least a basic knowledge of their students' home languages. This can be attributed to the language teachers being more aware of the benefits of language interactions and their cognitive benefits for the learners of additional languages (Jessner, 2003; Cenoz, 2009) but also of the importance of referring to the home language in their teaching practices.

Another variable that clearly shows differences among the participants is the educational context represented by the school type. As already stated, public and minority schools (both primary and secondary) differ in the learner population composition, with minority schools being exclusively attended by linguistic minority learners while public schools have Greek L1 majority of students but also students with numerous other home languages (see Mitits (2015)). Those working in minority primary schools do not only feel responsible for teaching Greek L1 but also for helping their students maintain their home language, a view partially shared by public primary school teachers. Secondary school teachers in minority schools have mixed feelings while their colleagues in public schools have a negative view. The same pattern is witnessed with other issues investigating the level of interlinguistic/intercultural sensitivity and interest in the multilingual background of their learners pointing towards the significance of the teaching context for the formation of views and beliefs. Apparently, primary school teachers are more positive to the issues of multilingualism in their classroom and, probably, have a better pedagogical background compared with the secondary school teachers who are under pressure to fulfil the requirement of rigid curricula and teach a much larger number of students in total. Next, the least experienced teachers seem to be more aware of the importance of maintaining the learners' home language for the learning of their L2 Greek. This can be attributed to their more recent university education which includes latest findings in the field of multilingualism.

Personal experience of other languages has yielded some significant results with respect to how teachers view their learners' prior language experience. The positive correlation between those who can speak other languages, have contact with speakers of other languages and are open to the possibility of learning their students' home languages, and those who refer to their students' home languages in their teaching practices is documented here. The particular teachers are more likely to create conditions in the classroom where additive rather than subtractive multilingualism can be developed (Jessner, 1995).

\section{Conclusion}

The study presented and discussed the views held by teachers with respect to their multilingual learners and the findings point towards the importance of raising awareness of the presence and characteristics of multilingual learners in schools and the need to improve upon teaching practices by offering in-service teacher training programs that would focus on taking advantage of the benefits of multilingualism.

\section{References}

Aronin, L. and D. Singleton, 2008. Multilingualism as a new linguistic dispensation. International Journal of Multilingualism, 5(1): 1-16. Viezw at Google Scholar 
Baker, C., 1996. Foundations of bilingualism and bilingual education. Clevedon: Multilingual Matters.

Baker, C. and J.S. Prys, 1998. Encyclopedia of bilingualism and bilingual education. Clevedon: Multilingual Matters.

Bialystok, E., 1991. Metalinguistic dimensions of bilingual language proficiency. In E. Bialystok (Ed.), Language processing in bilingual children. Cambridge: Cambridge University Press. pp: 113-140.

Borg, S., 2006. Teacher cognition and language education: Research and practice. London: Continuum.

Cenoz, J., 2009. Towards multilingual education: Basque educational research in international perspective. Bristol, UK: Multilingual Matters.

Cenoz, J., 2013. Defining multilingualism. Annual Review of Applied Linguistics, 33: 3-18. View at Google Scholar | View at Publisher

Cook, V., 1993. Wholistic multi-competence: Jeu d'esprit or paradigm shift? In B. Kettemann, W. Wieden (Eds), Current issues in European second language acquisition research. Tübingen: Narr. pp: 3-9.

Council of Europe, 2010. Guide for the development and implementation of curricula for plurilingual and intercultural education. Strasbourg: Language Policy Division.

Cummins, J., 1991. Language learning and bilingualism. Sophia Linguistica Monogragh, 29(1): 194-203. View at Google Scholar

Damanakis, M., 1997. The education of returnees and foreign students in Greece. [Education of Repatriated and Immigrant Students in Greece]. Athens: Gutenberg.

De Angelis, J., 2011. Teachers' beliefs about the role of prior language knowledge in learning and how these influence teaching practices. International Journal of Multilingualism, 8(3): 216-234. View at Google Scholar | View at Publisher

Genesee, F., R. Tucker and W. Lambert, 1975. Communication skills in bilingual children. Child Development, 46(4): 1010-1014. View at Google Scholar | View at Publisher

Georgoyannis, P., 2006. Greek as a second/foreign language. An intercultural approach [in Greek]. 9th International Conference on Intercultural Education, University of Patras.

Gkaintartzi, A. and R. Tsokalidou, 2011. She is a very good child but she doesn't speak: The invisibility of children's bilin gualism and teacher ideology. Journal of Pragmatics, 43(2): 588-60 1. View at Google Scholar | View at Publisher

Gogonas, N., 2010. Bilingualism and multiculturalism in Greek education: Investigating ethnic language maintenance among pupils of Albanian and Egyptian origin in Athens. Newcasle upon Tyne: Cambridge Scholars Publishing.

Govaris, C., S. Kaldi and S. Lolakas, 2010. Exploring the relationship between self esteem and school achievement of students with immigrant background and native students in the Greek primary school. In C. Govaris, S. Kaldi (Eds), The Educational Challenge of Cultural Diversity in the International Context. Germany: Waxmann Verlag GmbH. pp: 91-208.

Griva, E. and D. Chostelidou, 2012. Multilingual competence development in the Greek educational system: FL teachers' beliefs and attitudes. International Journal of Multilingualism, 9(3): 257-271. View at Google Scholar | View at Publisher

Gutierrez, E., 2014. Assessing 13 teachers' beliefs about multilingualism: Building, fine-tuning and validating a trilingual questionnaire. WoPaLP, 8: 80-115.

Hakuta, K., 1990. Language and cognition in bilingual children, bilingual education. In A. M. Padilla, H.H. Fairchild, C. M. Valadez (Eds), Issues and strategies in bilingual education. London/New Delhi: Sage Publications.

Hamers, J.F. and M.H.A. Blanc, 1989. Bilinguality and bilingualism. Cambridge: Cambridge University Press.

Haukas, A., 2016. Teachers' beliefs about multilingualism and a multilingual pedagogical approach. International Journal of Multilingualism, 13(1): 1-18. View at Google Scholar | View at Publisher

Herdina, P. and U. Jessner, 2002. A dynamic model of multilingualism: Perspectives of change in psycholinguistics. Clevedon: Multilingual Matters.

Heyder, K. and B. Schadlich, 2014. Mehrsprachigkeit und mehrkulturalitat-eine umfrage unter fremdsprachenlehrkraften in niedersachsen. Zeitschrift fur Interkulturellen Fremdsprachenun- Terricht, 19(1): 183-20 1. View at Google Scholar

Jespersen, O., 1922. Language. London: Allen and Unwin.

Jessner, U., 1995. How beneficial is bilingualism? Cognitive aspects of bilingual proficiency. In K. Sornig, D. Halwachs, C. Penzinger, G. Ambrosch (Eds), Linguistics with a human face. Graz: Institut für Sprachwissenschaft. pp: 173-182.

Jessner, U., 2003. On the nature of crosslinguistic interaction in multilinguals. In J. Cenoz, B. Hufeisen, U. Jessner (Eds), The multilingual Lexicon. Dordrecht: Kluwer. pp: 45-55.

Kecskes, I. and T. Papp, 2000. Foreign language and mother tongue. Mahwah, NJ: Lawrence Erlbaum.

Lambert, W., 1977. The effects of bilingualism on the individual: Cognitive and sociocultural consequences. In P. Hornby (Ed.), Bilingualism: Psychological, social and educational implications. New York: Academic Press. pp: 15-28.

Lasagabaster, D. and A. Huguet, 2007. Multilingualism in European bilingual contexts. Language use and attitudes. Clevedon: Multilingual Matters.

Malakoff, M., 1992. Translation skill and metalinguistic awareness in bilinguals. In R. Harris (Ed.), Cognitive processing in bilinguals. Amsterdam: North Holland. pp: 515-530.

Mitits, L., 2015. Language learning strategies and multilingualism: monolingual EFL and multilingual EFL/L2 Greek learners in Greek secondary education. Kavala, Greece: Saita Publications.

Nikolaou, G., 2000. Integration and education of foreign students at elementary school from "homogeneity" to multiculturalism. Integration and education of foreign students in primary school. From 'homogeneity' to multiculturalism. Athens: Ellinik Grammata.

Otwinowska, A., 2014. Does multilingualism influence plurilingual awareness of polish teachers of english? International Journal of Multilingualism, 11(1): 97-1 19. View at Google Scholar | View at Publisher

Reich, H., H.J. Roth, I. Dirim, J.N. Jörgensen, G. List, U. Neumann and V. Wurnig, 2002. Spracherwerb zweisprachig aufwachsender Kinder und Jugendlicher. Hamburg: Behorde fór Bildung und Sport.

Ricciardelli, L., 1992. Bilingualism and cognitive development in relation to threshold theory. Journal of Psycholinguistic Research, $21(4)$ : 301-3 16. View at Google Scholar | View at Publisher

Safont, J.M.P., 2005. Third language learners: Pragmatic production and awareness. Clevedon: Multilingual Matters.

Skourtou, E., 2002. Bilingual students in the Greek school, (Bilingual pupils in the Greek school. In M. Damanakis (Ed.), Epistimes Agogis , special issue on: Intercultural education in Greece. Practical Matters and Theoretical Questions. pp: 11-20.

Skourtou, E., 2008. Linguistic diversity and language learning and teaching: An example from Greece. Scientia Paedagogica Experimentalis 45(1): 175-194. View at Google Scholar

Titone, R., 1994. Bilingual education and the development of metalinguistic abilities: A research project. International Journal of Psycholinguistics, 10(1): 5-14. View at Google Scholar

Tressou, E. and S. Mitakidou, 2003. Education of linguistic minorities: Educators talk to educators about their experiences. Thessaloniki: Paratiritis. pp: $35-45$.

Tsokalidou, R., 2005. Raising bilingual awareness in Greek primary schools. International Journal of Bilingual Education and Bilingualism, 8(1): 2-13. View at Google Scholar | View at Publisher 
Appendix-1. Desriptive statistics for the 25 questionnaire items

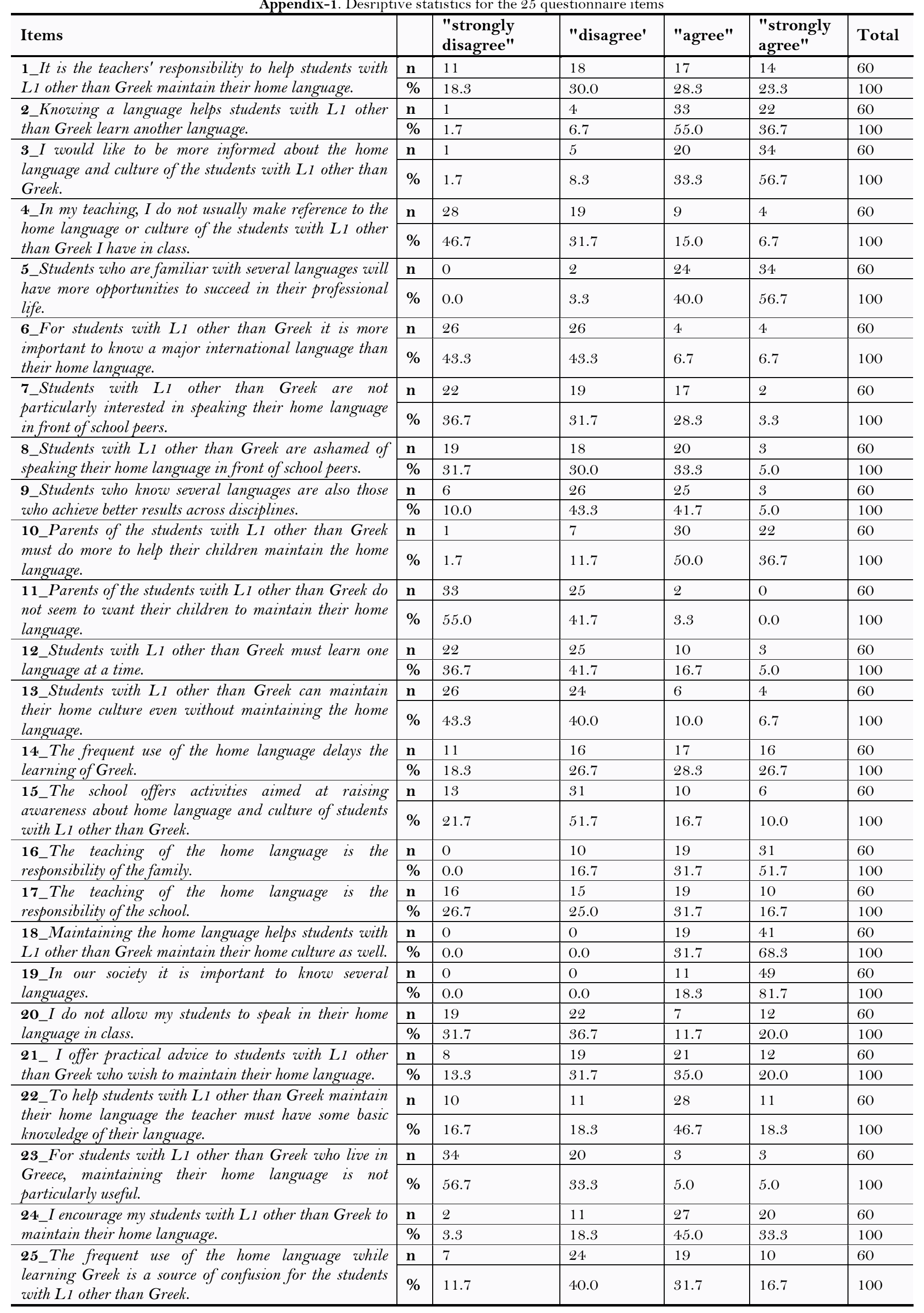


Appendix-2. The questionnaire items in order of teachers' preference

\begin{tabular}{|c|c|c|c|c|c|}
\hline Items (descending means) & $\mathbf{N}$ & Min. & Max. & Mean & SD \\
\hline 19. In our society it is important to know several languages. & 60 & 3.00 & 4.00 & 3.81 & .390 \\
\hline $\begin{array}{l}\text { 18. Maintaining the home language helps students with L1 other than Greek } \\
\text { maintain their home culture as well. }\end{array}$ & 60 & 3.00 & 4.00 & 3.68 & .469 \\
\hline $\begin{array}{l}\text { 5. Students who are familiar with several languages will have more opportunities to } \\
\text { succeed in their professional life. }\end{array}$ & 60 & 2.00 & 4.00 & 3.53 & .566 \\
\hline $\begin{array}{l}\text { 3. I would like to be more informed about the home language and culture of the } \\
\text { students with L1 other than Greek. }\end{array}$ & 60 & 1.00 & 4.00 & 3.45 & .723 \\
\hline 16. The teaching of the home language is the responsibility of the family. & 60 & 2.00 & 4.00 & 3.35 & .755 \\
\hline $\begin{array}{l}\text { 2. Knowing a language helps students with L1 other than Greek learn another } \\
\text { language. }\end{array}$ & 60 & 1.00 & 4.00 & 3.26 & .660 \\
\hline $\begin{array}{l}\text { 10. Parents of the students with L1 other than Greek must do more to help their } \\
\text { children maintain the home language. }\end{array}$ & 60 & 1.00 & 4.00 & 3.21 & .715 \\
\hline $\begin{array}{l}\text { 24. I encourage my students with L1 other than Greek to maintain their home } \\
\text { language. }\end{array}$ & 60 & 1.00 & 4.00 & 3.08 & .808 \\
\hline $\begin{array}{l}\text { 22. To help students with L1 other than Greek maintain their home language the } \\
\text { teacher must have some basic knowledge of their language. }\end{array}$ & 60 & 1.00 & 4.00 & 2.66 & .968 \\
\hline 14. The frequent use of the home language delays the learning of Greek. & 60 & 1.00 & 4.00 & 2.63 & 1.07 \\
\hline $\begin{array}{l}\text { 21. I offer practical advice to students with L1 other than Greek who wish to } \\
\text { maintain their home language. }\end{array}$ & 60 & 1.00 & 4.00 & 2.61 & .958 \\
\hline $\begin{array}{l}\text { 1. It is the teachers' responsibility to help students with L1 other than Greek } \\
\text { maintain their home language. }\end{array}$ & 60 & 1.00 & 4.00 & 2.56 & 1.04 \\
\hline $\begin{array}{l}\text { 14. The frequent use of the home language while learning Greek is a source of } \\
\text { confusion for the students with L1 other than Greek. }\end{array}$ & 60 & 1.00 & 4.00 & 2.53 & .910 \\
\hline $\begin{array}{l}\text { 9. Students who know several languages are also those who achieve better results } \\
\text { across disciplines. }\end{array}$ & 60 & 1.00 & 4.00 & 2.41 & .743 \\
\hline 16. The teaching of the home language is the responsibility of the school. & 60 & 1.00 & 4.00 & 2.38 & 1.05 \\
\hline 20. I do not allow my students to speak in their home language in class. & 60 & 1.00 & 4.00 & 2.20 & 1.10 \\
\hline $\begin{array}{l}\text { 15. The school offers activities aimed at raising awareness about home language } \\
\text { and culture of students with L1 other than Greek. }\end{array}$ & 60 & 1.00 & 4.00 & 2.15 & .879 \\
\hline $\begin{array}{l}\text { 8. Students with L1 other than Greek are ashamed of speaking their home language } \\
\text { in front of school peers. }\end{array}$ & 60 & 1.00 & 4.00 & 2.11 & .922 \\
\hline $\begin{array}{l}\text { 7. Students with L1 other than Greek are not particularly interested in speaking } \\
\text { their home language in front of school peers. }\end{array}$ & 60 & 1.00 & 4.00 & 1.98 & .892 \\
\hline 12. Students with L1 other than Greek must learn one language at a time. & 60 & 1.00 & 4.00 & 1.9 & .857 \\
\hline $\begin{array}{l}\text { 4. In my teaching, I do not usually make reference to the home language or culture of } \\
\text { the students with L } 1 \text { other than Greek I have in class }\end{array}$ & 60 & 1.00 & 4.00 & 1.81 & .929 \\
\hline $\begin{array}{l}\text { 13. Students with L1 other than Greek can maintain their home culture even } \\
\text { without maintaining the home language. }\end{array}$ & 60 & 1.00 & 4.00 & 1.80 & .879 \\
\hline $\begin{array}{l}\text { 6. For students with } L 1 \text { other than Greek it is more important to know a major } \\
\text { international language than their home language. }\end{array}$ & 60 & 1.00 & 4.00 & 1.76 & .851 \\
\hline $\begin{array}{l}\text { 23. For students with L1 other than Greek who live in Greece, maintaining their } \\
\text { home language is not particularly useful. }\end{array}$ & 60 & 1.00 & 4.00 & 1.58 & .808 \\
\hline $\begin{array}{l}\text { 11. Parents of the students with L1 other than Greek do not seem to want their } \\
\text { children to maintain their home language. }\end{array}$ & 60 & 1.00 & 3.00 & 1.48 & .567 \\
\hline Valid N (listwise) & 60 & & & & \\
\hline
\end{tabular}

